\title{
FAKTOR YANG MEMPENGARUHI AKSEPTOR KB INDOPLANT TERHADAP KONTROL ULANG DI PUSKESMAS TANJUNG BERINGIN .
}

\author{
Factors Affecting Indoplant Kb Acceptors On \\ Re-Control In Health Center \\ Tanjung Beringin \\ Arnof Yerni \\ STIkes Putra Abadi Langkat Stabat \\ arnofy@yahoo.com
}

\author{
Riwayat Artikel \\ Diajukan: Januari 2020 \\ Diterima: Maret 2020 \\ Penulis Korespondensi: \\ - Arnof Yerni \\ - STIkes Putra Abadi \\ Langkat Stabat \\ -arnofy@yahoo.com
}

\section{Kata Kunci:}

Akseptor Indoplant

,Kontrol Ulang

\begin{abstract}
ABSTRAK
Indoplant sebagai salah satu metode Alat kontrasepsi bawah kulit, secara resmi digunakan di beberapa negara termasuk Indonesia dan diterima dengan cepat oleh masyarakat dan menjadi salah satu metode kontrasepsi pilihan yang diprogramkan. Akan tetapi masih banyak akseptor yang tidak melaksanakan kontrol ulang setelah pemasangan.Penelitian ini bertujuan untuk mengetahui faktor faktor yang memepengaruhi akseptor Indoplant dalam melaksanakan kontrol ulang di Puskesmas TanjungBerigin Kabupaten Langkat tahun 2018. Penelitian ini ini menggunakan desain deskriptip dengan pendekatan cross secsional. Populasi dalam penelitian ini adalah adalah seluruh akseptor indoplant pasca pemasangan 13 bulan di Puskesmas Tanjung Beringin, sebanyak 68 orang dan teknik pengambilan sampel adalah total sampling.

Hasil analisa univariat umur responden tertinggi $>35$ tahun 37 orang $(54,4 \%)$ pendidikan tinggi 42 orang $(61,8 \%)$ paritas tinggi 41 orang $(60,3 \%)$, pengetahuan tinggi 39 orang $(57,4 \%)$ dan yang melaksanakan kontrol ulang 53 orang $(77,9 \%)$. Sedangkan hasil analisa bivariat menggunakan uji chi square (CI 95\% dan $\alpha=0,05)$ didapatkan pengaruh umur terhadap kontro ulang $(\mathrm{p}$ - value $=1000)$ dan pengaruh pendidikan $(\mathrm{p}-$ value $=0,023)$ dan pengaruh paritas $(p$-value $=0,034)$ dan pengaruh pengetahuan ( $\mathrm{p}$ - value $=0,015)$.

Berdasarkan hasil penelitian diharapkan pada petugas kesehatan khususnya bidan untuk dapat memberikan penyuluhan atau informasi yang lengkap tentang indoplant khususnya pelaksanaan kontrol ulang.
\end{abstract}

Kata kunci : Akseptor indoplant,kontrol ulang

ABSTRACT
Indoplant as one of the methods of contraception under the skin, is officially used in several countries including Indonesia and is quickly accepted by the public and is one of the programmed methods of contraception. However, there are still many acceptors who do not carry out re-control after installation. This study aims to determine the factors that influence the Indoplant acceptors in carrying out re-control at TanjungBerigin Health Center in Langkat Regency in 2018. This study uses a descriptive design with cross-sectional 
approach. The population in this study were all indoplant acceptors after 13 months installation at Tanjung Beringin Health Center, as many as 68 people and the sampling technique was total sampling .

The result of univariate analysis was the highest age of respondents $>=0.05)$ found the effect of age on the re-contro $(p$-value $=1000)$ and the influence of education $(p$-value $=0.023)$ and the influence of parity ( $p$-value $=0.034)$ and the influence of knowledge $(p$-value $=0.015) . \alpha 35$ years 37 people (54.4\%) higher education 42 people (61.8\%) high parity 41 people (60.3\%), high knowledge 39 people (57.4\%) and those who re-controlling 53 people (77.9\%). While the results of the bivariate analysis using the chi square test $(95 \%$ CI and Based on the results of the study it is expected that health workers, especially midwives, can provide counseling or complete information about indoplant, especially the implementation of re-control.

Keywords: Indoplant acceptors, re-control

\section{PENDAHULUAN}

Kependudukan adalah salah satu masalah besar dan pelik yang dihadapi bangsa Indonesia sejak kemerdekaan sampai sekarang ini. Secara garis besar masalah-masalah pokok di bidang kependudukan yang dihadapi Indonesia adalah jumlah penduduk yang besar dengan laju pertumbuhan penduduk yang relatif masih tinggi, persebaran penduduk yang tidak merata, struktur umur muda, dan kualitas penduduk yang masih harus ditingkatkan(1).

Indonesia saat ini menempati urutan keempat jumlah penduduk terbesar di dunia setelah China, India, dan Amerika Serikat. Laju pertumbuhan penduduk Indonesia memang sudah bisa diturunkan dari 2,32\% per tahun pada tahun 1980 menjadi $1,97 \%$ per tahun pada tahun 1990(2).

Selain itu juga telah berhasil menurunkan Angka Kematian Ibu (AKI) dari 390 per 100.000 kelahiran pada tahun 1994 menjadi 307 per 100.000 kelahiran hidup tahun 2002 2003(3).

Keberhasilan menurunkan angka pertumbuhan penduduk ini adalah hasil yang luar biasa dari pelaksanaan program keluarga berencana yang dilaksanakan di bawah koordinasi Badan Koordinasi Keluarga Berencana Nasional, disingkat BKKBN, sejak tahun 1970 sampai sekarang ini. Salah satu bentuk pelayanan keluarga berencana adalah pelayanan kontrasepsi yaitu upaya untuk mencegah terjadinya kehamilan yang dapat bersifat sementara dan dapat juga bersifat permanen (4).

Pada saat ini berkat kemajuan pembangunan, ilmu dan teknologi kedokteran, metode kontrasepsi yang tersedia banyak macamnya. Namun walaupun demikian, guna lebih meningkatkan efektifitas dan efisiensi program pelayanan kontrasepsi di Indonesia lebih diprioritaskan pada metode yang bersifat efektif, jangka panjang dan mantap. Metode tersebut ialah Intrauterine Device disingkat IUD dan Implant atau Alat Kontrasepsi Bawah Kulit/AKBK, serta kontrasepsi Medis Operatif atau kontrasepsi mantap yang secara keseluruhan dikenal dengan nama MKET atau Metode Kontrasepsi Efektif Terpilih (2).

Penggunaan alat kontrasepsi hormonal masih tetap mendominasi atau menjadi pilihan utama akseptor di Indonesia yaitu metode suntikan $27,8 \%$, pil $13,2 \%$, dan implant atau susuk keluarga berencana $14,3 \%$. Sedangkan metode non hormonal adalah IUD $6,2 \%$, kondom $0,9 \%$, Medis Operatif Wanita (MOW) 3,7\%, dan Medis Operatif Pria (MOP) 0,4\% (5).

Indoplant sebagai salah satu metode Alat kontrasepsi bawah kulit, secara resmi digunakan di beberapa negara termasuk Indonesia sejak tahun 
1987 dan diterima dengan cepat oleh masyarakat dan menjadi salah satu metode kontrasepsi pilihan yang diprogramkan. Jumlah pemakaian indoplant di Indonesia paling tinggi di dunia. Pada bulan Maret 1995 terdapat lebih dari 1.800 .000 akseptor pengguna indoplant di seluruh Indonesia. Sampai Maret 1999 terdapat 2.882.899 akseptor implant atau sebanyak $10,8 \%$ dari seluruh akseptor kontrasepsi di Indonesia yang berjumlah 26.729.030 akseptor. Saat ini pemakaian Alat Kontrasepsi Bawah Kulit (AKBK) atau yang lebih populer dengan nama Indoplant di Indonesia adalah 14,3\% dari seluruh akseptor keluarga berencana aktif (6).

Efektifitas indoplant sangat tinggi yaitu 0,2 - 1,0 kehamilan per 100 perempuan,tingkat kelahiran pada tahun pertama pemakaian hanyalah $0,2 \%$. Pada tahun kedua $0,5 \%$, pada tahun ketiga $1,2 \%$, dan pada tahun keempat $1,6 \%$. Secara keseluruhan tingkat kehamilan yang mungkin ditimbulkan dalam jangka 3 - 5 tahun pemakaian adalah 3,9\%. Sedangkan tingkat fertilitas kembali pasca pemakaian implant adalah sekitar $80-90 \%$ wanita dapat hamil kembali pada 1 tahun setelah pengangkatan indoplant (7).

Permasalahan utama yang muncul dalam penggunaan implant adalah jumlah akseptornya yang mengakhiri pemakaian cukup tinggi. Hal ini disebabkan karena efek samping yang timbul, bisa jadi karena tidak dilakukannya pemeriksaan sebelum pemasangan, karena adanya program pencapaian target sehingga kepentingan akseptor kurang mendapat perhatian serta kurangnya pengetahuan dan pelaksanaan kontrol ulang pasca pemasangan. Permasalahan kontrol ulang yang kurang adekuat ini diduga disebabkan beberapa faktor seperti kurang mengertinya akseptor tentang jadwal dan tata cara kontrol ulang sehingga akseptor tidak melaksanakan kontrol ulang sebagaimana mestinya. Pada penelitian didapat angka penghentian pemakaian oleh akseptor indoplant yang tidak mendapat penerangan yang cukup tentang efek samping adalah $10,5 \%$ selama 1 tahun, sedangkan kelompok yang mendapat penerangan yang cukup tentang gangguan pendarahan adalah bukan hal yang berbahaya, didapat angka penghentian 5,2\% (8).

Akseptor indoplant yang paling banyak umur > 35 tahun karena sebaiknya menghentikan atau mengakhiri kesuburan setelah mempunyai 2 orang anak dan kontrasepsi yang diperlukan adalah efektifitas sangat tinggi, dapat dipakai untuk jangka panjang, tidak menambah kelainan yang sudah ada dengan demikian untuk kontrol ulangnya juga kebanyakan umur > 35 tahun, penggunaan indoplant (AKBK) dianjurkan pada fase menjarangkan kehamilan dan mengakhiri kehamilan atau kesuburan dengan jumlah anak 2 orang dan jarak antara kelahiran $2-4$ tahun demikian juga dengan kontrol ulangnya (9). Jumlah akseptor yang tercatat di Puskesmas Tanjung Beringintahun 2018 sebanyak 125 orang didapati yang drop out sekitar $15 \%$ atau sekitar 25 orang

Berdasarkan latar belakang di atas dimana banyaknya akseptor yang mengakhiri pemasangan sebelum masa waktunya disebabkan karena kurangnya pengetahuan dan pelaksanaan kontrol ulang pasca pemasangan, diduga kurang mengertinya akseptor tentang jadwal dan tata cara kunjungan ulang maka berdasarkan itu penulis ingin melakukan penelitian tentang "Faktor faktor Yang Mempengaruhi Akseptor Keluarga Berencana Metode Indoplant ( Alat Kontrasepsi Bawah Kulit) terhadap 
Pelaksanaan Kontrol Ulang di Puskesmas Tanjung Beringin Kecamatan Hinai Kabupaten Langkat tahun 2018".

\section{METODE PENELITIAN}

Penelitian ini dilakukan di PuskesmasTanjung Beringin Kecamatan HinaiKabupaten Langkat Propinsi Sumatera Utara. Penelitian ini akan dilakukan padabulan Januari 2018 sampai Februari 2018

Populasi dalam penelitian ini adalah seluruh akseptor indoplant pasca pemasangan 13 bulan di Puskesmas Tanjung Berigin Kecamatan Hinai Kabupaten Langkat tahun 2018, sebanyak 68 orang.
Pada penelitian ini, analisa dengan metode statistik univariat akan digunakan untuk menganalisa tingkat pengetahuan ibu terhadap pelaksanaan kontrol ulang indoplant. Untuk uji hipotesa yang digunakan adalah chi square tes dengan kemaknaan signifikan 0,05 untuk mengetahui apakah terdapat hubungan yang bermakna antara prilaku dan pelaksanaan kontrol ulang. Rumus

$$
\begin{aligned}
& \mathrm{X}^{2}=\Sigma \frac{(\mathrm{O}-\mathrm{E})^{2}}{\mathrm{E}} \\
& \mathrm{X}^{2}=\text { Chi square } \\
& \mathrm{O}=\text { Nilai Observasi } \\
& \mathrm{E}=\text { standar error }
\end{aligned}
$$

\section{HASIL PENELITIAN}

\section{Analisa Univariat}

Tabel 1. Distribusi responden akseptor indoplant berdasarkan umur di Puskesmas Tanjung Beringin Kecamatan Hinai Kabupaten Langkat tahun 2018

\begin{tabular}{ccc}
\hline Umur & Frekuensi (n) & Persentase (\%) \\
\hline$>35$ & 37 & 54,4 \\
$<35$ & 31 & 45,6 \\
\hline Total & 68 & 100 \\
\hline
\end{tabular}

Dari tabel 1 dapat dilihat mayoritas responden umur $>35$ tahun sebanyak 37 orang $(54,4 \%)$ dan minoritas umur
$<35$ tahun tahun sebanyak 31 orang $(45,6 \%)$.

\begin{tabular}{|c|c|c|}
\hline Tingkat Pendidikan & Frekuensi (n) & Persentase (\%) \\
\hline Tinggi & 42 & 61,8 \\
\hline Rendah & 26 & 38,2 \\
\hline Total & 68 & 100 \\
\hline
\end{tabular}

Tabel 2. Distribusi Responden Akseptor Indoplant Berdasarkan Pendidikan Di Puskesmas Tanjung Beringin Kecamatan Hinai Kabupaten Langkat Tahun 2018

Dari tabel diatas dapat dilihat bahwa mayoritas responden berpendidikan tinggi sebanyak 25 orang $(61,8 \%)$ dan berpendidikan rendah 26 orang $(38,2 \%)$ 
Tabel 3. Distribusi Responden Akseptor Indoplant Berdasarkan Paritas Di Puskesmas Tanjung Beringin Kecamatan Hinai Kabupaten Langkat Tahun 2018

\begin{tabular}{cll}
\hline Paritas & Frekuensi (n) & Persentase $(\%)$ \\
\hline Tinggi & 41 & 60,3 \\
Rendah & 27 & 39,7 \\
\hline Total & 100 & 100 \\
\hline
\end{tabular}

Dari tabel diatas dapat dilihat mayoritas responden paritas tinggi sebanyak 41 orang $(60,3 \%)$ dan minoritas patitas rendah 27 orang $(39,7 \%)$.

Tabel 4. Distribusi Tingkat Pengetahuan Akseptor Indoplant Di Puskesmas Tanjung Beringin Kecamatanhinai Kabupaten Langkat Tahun 2018.

\begin{tabular}{lll}
\hline Tingkat Pengetahuan & Frekuensi (n) & Presentase (\%) \\
\hline Tinggi & 39 & 57,4 \\
Rendah & 29 & 42,6 \\
\hline Total & 100 & 100 \\
\hline
\end{tabular}

Dari tabel 4 dapat dilihat responden yang berpengetahuan tinggi sebanyak
39 orang $(57,4 \%)$ dan berpengetahuan rendah sebanyak 29 orang $(42,6 \%)$

Tabel 5. Distribusi Pelaksanaan Kontrol Ulang Akseptor Indoplant Di Puskesmas Tanjung Beringin Kecamatan Hinai Kabupaten Langkat Tahun 2018

\begin{tabular}{lll}
\hline Pelaksanaan kontrol ulang & Frekuensi (n) & Presentase (\%) \\
\hline Kontrol & 53 & 77,9 \\
Tidak Kontrol & 15 & 22,1 \\
\hline Total & 100 & 100 \\
\hline
\end{tabular}

Dari tabel diatas dapat dilihat responden tidak melakukan kunjungan ulang 15 yang melakukan kunjungan ulang orang $(22,1 \%)$. sebanyak 53 orang $(77,9 \%)$ dan yang

\section{Analisa Bivariat}

Analisa bivariat dalam penelitian untuk melihat faktor faktor yang mempengaruhi akseptor indoplant melaksanankan kontrol ulang.denganmenggunakan uji chi squaretest $\left(\chi^{2}\right)$ dengan taraf kemaknaan $95 \%$.

Tabel 6. Hubungan Umur Dengan Pelaksanaan Kontrol Ulang Di Puskesmas Tanjung Beringin Kecamatan Hinai Kabupaten Langkat Tahun 2018.

\begin{tabular}{|c|c|c|c|c|c|c|c|c|c|}
\hline & \multirow{3}{*}{$\begin{array}{c}\text { Variabel } \\
\text { Independen }\end{array}$} & \multicolumn{6}{|c|}{ Pelaksanaan Kontrol Ulang } & \multirow{3}{*}{$\begin{array}{c}\text { Nilai } \\
X^{2}\end{array}$} & \multirow{3}{*}{ Nilai $p$} \\
\hline & & \multicolumn{2}{|c|}{ Kontrol } & \multicolumn{2}{|c|}{ Tidak Kontrol } & \multicolumn{2}{|c|}{ Total } & & \\
\hline & & $\mathbf{n}$ & $\%$ & $\mathbf{n}$ & $\%$ & $\mathbf{N}$ & $\%$ & & \\
\hline \multicolumn{10}{|c|}{ Umur } \\
\hline 1 & Tua $(>35)$ & 29 & 78,4 & 8 & 21,6 & 37 & 100 & \multirow{2}{*}{1,057} & \multirow{2}{*}{1,000} \\
\hline 2 & Muda $(<35)$ & 24 & 77,4 & 7 & 22,6 & 31 & 100 & & \\
\hline
\end{tabular}


Berdasarkan tabulasi silang, diperoleh bahwa sebanyak 29 responden $(78,4 \%)$ yang umur tua melaksanakan kontrol ulang denagan baik pada kontrol ulang setelah pemasangan indoplant serta diperoleh umur muda sebanyak 7 orang $(22,6 \%)$ tidak melaksanakan kontrol ulang pasca pemasangan indoplant.

Hasil analisis bivariat dengan uji chi square didapat nilai $p=1,000$, artinya tidak ada hubungan yang signifikan antara umur dengan pelaksanaan kontrol ulang pada pasien indoplant.

Tabel 7. Hubungan Antara Pendidikan Dengan Pelaksaan Kontrol Ulang Di Puskesmas Tanjung Beringin Kecamatan Hinai Kabupaten Langkat Tahun 2018.

\begin{tabular}{|c|c|c|c|c|c|c|c|c|c|}
\hline & \multirow{3}{*}{$\begin{array}{c}\text { Variabel } \\
\text { Independen }\end{array}$} & \multicolumn{6}{|c|}{ Pelaksanan Kontrol Ulang } & \multirow{3}{*}{$\begin{array}{c}\text { Nilai } \\
X^{2}\end{array}$} & \multirow{3}{*}{ Nilai $p$} \\
\hline & & \multicolumn{2}{|c|}{ Kontrol } & \multicolumn{2}{|c|}{ Tidak Kontrol } & \multicolumn{2}{|c|}{ Total } & & \\
\hline & & $\mathbf{n}$ & $\%$ & $\mathbf{n}$ & $\%$ & $\mathbf{N}$ & $\%$ & & \\
\hline \multicolumn{10}{|c|}{ Pendidikan } \\
\hline 1 & Tinggi & 37 & 88,1 & 5 & 11,9 & 42 & 100 & \multirow{2}{*}{4,625} & \multirow{2}{*}{0,023} \\
\hline 2 & Rendah & 16 & 61,5 & 10 & 38,5 & 26 & 100 & & \\
\hline
\end{tabular}

Berdasakan tabulasi silang, dapat diketahui bahwa persentase pendidikan yang rendah yang tidak melaksanakan kontrol sebanyak 10 orang $(38,5 \%)$ dan yang pendidikan tinggi melaksanakan kontrol ulang sebanyak 37 orang $(88,1 \%)$
Hasil analisis bivariat dengan uji chi square didapat nilai $p=0,023,(\mathrm{p}<$ $0,05)$. artinya ada hubungan yang signifikan antara pendidikan dengan pelaksanaan kontrol ulang pada pasien indoplant.

Tabel 8. Hubungan Paritas Dengan Pelaksaan Kontrol Ulang Di Puskesmas Tanjung Beringin Kecamatan Hinai Kabupaten Langkat Tahun 2018.

\begin{tabular}{|c|c|c|c|c|c|c|c|c|c|}
\hline & \multirow{3}{*}{$\begin{array}{c}\text { Variabel } \\
\text { Independen }\end{array}$} & \multicolumn{6}{|c|}{ Pelaksanaan kontrol ulang } & \multirow{3}{*}{$\begin{array}{c}\text { Nilai } \\
X^{2}\end{array}$} & \multirow{3}{*}{$\begin{array}{l}\text { Nilai } \\
p\end{array}$} \\
\hline & & \multicolumn{2}{|c|}{ Kontrol } & \multirow{2}{*}{$\begin{array}{c}\text { Tidal } \\
\mathbf{n}\end{array}$} & \multirow{2}{*}{$\begin{array}{c}\text { Kontrol } \\
\%\end{array}$} & \multicolumn{2}{|c|}{ Total } & & \\
\hline & & $\mathbf{n}$ & $\%$ & & & $\mathbf{n}$ & $\%$ & & \\
\hline \multicolumn{10}{|c|}{ Paritas } \\
\hline 1 & Tinggi & 36 & 87,8 & 5 & 12,2 & 41 & 100 & \multirow{2}{*}{4,235} & \multirow{2}{*}{0,034} \\
\hline 2 & Rendah & 17 & 63,0 & 10 & 37,0 & 27 & 100 & & \\
\hline
\end{tabular}

Berdasakan tabulasi silang, diketahui bahwa persentase paritas rendah pada pelaksanaan kontrol ulang pada pasien indoplant yang tidak melaksanakan, yaitu sebesar 10 orang $(37,0 \%)$. Persentase paritas tinggi pada pelaksanaan kontrol ulang pada pasien Indoplant yang melaksanakan tertinggi sebanyak, yaitu sebesar 36 orang $(87,8 \%)$

Hasil analisis bivariat dengan uji chi square didapat nilai $p=0,034$, artinya ada hubungan yang signifikan antara paritas dengan pelaksanaan kontrol ulang pada pasien Indoplant.. 
Tabel 9. Hubungan Pengetahuan Dengan Pelaksaan Kontrol Ulang Di Puskesmas Tanjung Beringin Kecamatan Hinai Kabupaten Langkat Tahun 2018

\begin{tabular}{|c|c|c|c|c|c|c|c|c|}
\hline \multirow{3}{*}{$\begin{array}{c}\text { Variabel } \\
\text { Independen }\end{array}$} & \multicolumn{6}{|c|}{ Pelaksanaan Kontrol Ulang } & \multirow{3}{*}{$\begin{array}{c}\text { Nilai } \\
\mathbf{X}^{2}\end{array}$} & \multirow{3}{*}{$\begin{array}{c}\text { Nilai } \\
p\end{array}$} \\
\hline & \multicolumn{2}{|c|}{ Kontrol } & \multicolumn{2}{|c|}{$\begin{array}{c}\text { Tidak } \\
\text { Kontrol } \\
\end{array}$} & \multicolumn{2}{|c|}{ Total } & & \\
\hline & $\mathbf{n}$ & $\%$ & $\underline{\mathbf{n}}$ & $\%$ & $\mathbf{n}$ & $\%$ & & \\
\hline \multicolumn{9}{|l|}{ Pengetahuan } \\
\hline 1 Tinggi & 35 & 89,7 & 4 & 10,3 & 41 & 100 & \multirow{2}{*}{5,347} & \multirow{2}{*}{0,015} \\
\hline 2 Rendah & 18 & 62,1 & 11 & 37,9 & 29 & 100 & & \\
\hline
\end{tabular}

Berdasakan tabulasi silang, diketahui bahwa persentase pengetahuan yang tidak kontrol ulang tetinggi pada pelaksanaan konrtol ulang pasien indoplant yang tertinggi , yaitu sebesar 11 orang $(37,9 \%)$. Persentase pengetahuan yang tinggi terbanyak pada pelaksanaan kontrol ulang, yaitu sebesar 35 orang $(89,7 \%)$.

Hasil analisis bivariat dengan uji chi square didapat nilai $p=0,015$, artinya ada hubungan yang signifikan antara pengetahuan dengan pelaksanaan kontrol ulang pasien indoplant.

\section{PEMBAHASAN}

\section{Pengaruh umur terhadap}

Pelaksanaan kontrol ulang pada pasien indoplant.

Berdasarkan hasil analisis uji statistik menunjukkan umur tidak mempunyai pengaruh yang signifikan terhadap pelaksanaan kontrol ulang pada pasien indoplant, dengan nilai $p=$ 1.000 (> 0,05). Hasil penelitian ini menguatkan hasil penelitian sebelumnya yang dilakukan Ramina (2010), yang menyatakan bahwa ada hubungan antara umur terhadap pelaksanaan kontrol ulang pasien indoplant.

Menurut Hurlock dalam Mutiah bahwa usia dewasa (18 - 40 tahun) merupakan masa dimana seseorang secara maksimal mencapai prestasi yang memuaskan. Pada usia tengah $(41-60$ tahun) tinggal mempertahankan prestasi yang dicapai pada usia dewasa. Sedangkan usia tua (> 60 tahun) adalah usia tidak produktif lagi(10).

Menurut asumsi penulis hal ini menunjukkan bahwa umur yang tua tidak mempengaruhi pelaksanaan kontrol ulang dan umur yang relatif muda juga tidak mempengaruhi akan melaksanakan ulang dengan baik.

\section{Pengaruh pendidikan terhadap Pelaksanaan kontrol ulang pada pasienindoplant.}

Hasil analisis bivariat dengan uji chi square didapat nilai $p=0,023,(\mathrm{p}<$ 0,05). artinya ada hubungan yang signifikan antara pendidikan dengan pelaksanaan kontrol ulang pada pasien indoplant. hal tersebut menunjukkan bahwa variabel pendidikan berpengaruh terhadap pelaksanaan kontrol ulang pasien Indoplant.

Menurut Survey Demografi Kesehatan Indonesia bahwa tingkat pendidikan mempunyai hubungan yang erat dengan faktor - faktor pemakaian alat atau cara KB. Pendidikan juga merupakan salah satu faktor yang mempengaruhi persepsi seseorang karena dapat membuat seseorang lebih mudah menerima ide-ide baru(9).

Makin tinggi pendidikan seseorang maka diharapkan stok modal manusianya (pengetahuan dan keterampilan) akan semakin meningkat. 


\section{Pengaruh paritas terhadap Pelaksanaan kontrol ulang pada pasien indoplant.}

Hasil analisis bivariat dengan uji chi square didapat nilai $p=0,034$, artinya ada hubungan yang signifikan antara paritas dengan pelaksanaan kontrol ulang pada pasien Indoplant..

Pasien yang paritas tinggi cenderung melakukan pelaksanaan kontrol ulang dengan baik dibandingkan pasien yang paritas rendah tidak melakukan pelaksanaan kontrol ulang.

Menurut Notoatmodjo bahwa pengalaman adalah guru yang paling baik yaitu bahwa pengalaman merupakan sumber pengetahuan atau pengalaman itu adalah suatu cara untuk memperoleh kebenaran pengetahuan. Oleh karena itu pengalaman pribadi pun dapat digunakan sebagai upaya memperoleh pengetahuan. Hal ini sesuai dengan penyajian hasil penelitian yang memperlihatkan bahwa kategori paritas tinggi yang melaksanakan kontrol ulang dengan baik terdapat pada paritas tinggi atau multipara(11).

Paritas mempunyai pengaruh pada pelaksanaan kontrol ulang pasien indoplant yang artinya yang paritas tinggi akan mempunyai pengalaman yang lebih banyak untuk melaksanakan kontrol ulang dengan baik.

\section{Pengaruh pengetahuan terhadap Pelaksanaan kontrol ulang pada pasien indoplant.}

Hasil analisis bivariat dengan uji chi square didapat nilai $p=0,015$, artinya ada hubungan yang signifikan antara pengetahuan dengan pelaksanaan kontrol ulang pasien indoplant.

Hasil penelitian sesuai dengan hasil penelitian Rahmayanti, pengetahuan mempunyai pengaruh terhadap pelaksanaan kontrol ulang
AKBK. Dari 40 respondennya yang berpengetahuan baik sebanyak 18 orang (45\%) berpengetahuan cukup sebanyak 12 orang $(30 \%)$ berpengetahuan kurang sebanyak sebanyak 10 orang (25\%),dan rata rata yang berpengetahuan kurang tidak melakukan kunjungan ulang dengan tingkatan pendidikan $\mathrm{SD}(6)$

Menurut asumsi penulis semakin baik tingkat pengetahuan seseorang tentang AKBK maka pengetahuannya mengenai indikasi, efek samping, komplikasi akibat pemasangan AKBK akan semakin baik.

Hal ini akan berpengaruh terhadap pelaksanaan kontrol ulang, dikarenakan dengan melakukan kontrol ulang seseorang akan dapat mengetahui secara dini apa yang menjadi efek samping dan komplikasi pemasangan AKBK.P engetahuan dengan pelaksanaan kontrol ulang pada pasien indoplant. yang artinya pengetahuan mempunyai pengaruh pada pelaksanaan kontrol ulang pasien indoplant yang artinya yang pengetahuan tinggi akan mempunyai pengalaman yang lebih banyak untuk melaksanakan kontrol ulang dengan baik.

\section{KESIMPULAN DAN SARAN Kesimpulan}

Berdasarkan hasil penelitian dan pembahasan dapat diambil beberapa kesimpulan sebagai berikut: yang mana umur tidak berpengaruh pada pelaksanaan kontrol ulang pasien indoplant sedangkan pendidikan,paritas dan pengetahuan menpunyai pengaruh yang signifikan terhadap pelaksanaan kontrol ulang pasien indoplant.

\section{DAFTAR PUSTAKA}

1. Wiknjosastro $H$, Saifuddin $A B$, Rachimhadhi T. Ilmu bedah kebidanan. Jakarta Bina Pustaka. 2010; 
2. BKKBN U. Survey Demografi dan Kesehatan 2012: Modul Pria [Internet]. Jakarta; 2014.

3. Dezarino M, Ichsan TM, Prabudi MO. Penggunaan kontrasepsi implan 2 batang selama 1 tahun. Maj Kedokt Nusant J Med Sch. 45(2).

4. Handayani L, Suharmiati S, Hariastuti I, Latifah C. Peningkatan Informasi tentang KB: Hak Kesehatan Reproduksi yang perlu Diperhatikan oleh Program Pelayanan Keluarga Berencana. Bul Penelit Sist Kesehat. 2012;15(3 Jul).

5. Sari deaa. Penerapan konseling Menggunakan Buku Saku Terhadap Keputusan Pengguna $\mathrm{Kb}$ Implant diBPM Teguh Rahayuningsih Karangsari Buayan Kebumen. Stikes Muhammadiyah Gombong; 2016.

6. Rahmayanti OM. Hubungan Antara Tingkat Pendidikan Dan Pendapatan Dengan Tingkat Partisipasi Pus Dalam Pelaksanaan Program Keluarga Berencana Di Desa Menganti Kecamatan Kesugihan Kabupaten Cilacap Tahun 2015. Universitas Negeri Semarang; 2015.

7. Husada SK. Hubungan Antara Karakteristik Demografi Suami Akseptor Kb Dengan Pemilihan Alat Kontrasepsi Dalam Rahim (Akdr) Di Puskesmas.

8. Dayanti JK, Soeharto BP, Adespin DA. Faktor-Faktor Yang Berhubungan Dengan Penggunaan Metode Kontrasepsi Pada Pasangan Usia Subur Di RowosarI. Faculty of Medicine; 2018.

9. DEWI M. Hubungan Penggunaan Kontrasepsi Implant Dengan
Kenaikan Berat Badan Di

Puskesmas Panga Kabupaten Aceh Jaya Tahun 2018. Institut Kesehatan Helvetia; 2018.

10. Mutiah D. Psikologi bermain anak usia dini. Kencana; 2015.

11. Notoatmodjo S. Metododologi penelitian kesehatan. 2010; 